\title{
THE CATECHISM OF DESTRUCTION: SERGEI NECHAEV AND THE SPIRIT OF NIHILISM
}

\author{
Ph.D. Georgios Karakasis \\ Independent researcher, Doctor in Philosophy \\ (University of the Basque Country) Pamplona/Iruñea, \\ SPAIN \\ E-mail: geokarakasis7@yahoo.com
}

\begin{abstract}
In this article our aim is to attempt a philosophical interpretation of the phenomenon of political nihilism the way the latter is developed in the life and thought of the Russian anarchist Sergei Nechaev. Taking a deeper look at his pamphlet Catechism of a Revolutionary and aided by the profound analysis of the anarchist's thought made by Fyodor Dostoevsky, we will try to show how nihilism may break every possible bond between the individual and the society opening, thus, the path for the possible appearance of more Nechaevs and Nechaevists in the modern world.
\end{abstract}

Keywords: nihilism; Nechaev; destruction; Dostoevsky;

\section{INTRODUCION}

Our aim in this paper is to take a closer look, from a philosophical angle, to the thought of the Russian radical anarchist Sergei Nechaev- especially, to his work Catechism of the Revolutionary- in order to better understand what political nihilism is and how it is still able to mobilize groups or find supporters in various actors of the ideological spectrum.

In the first part we will embark upon a brief presentation of Nechaev's life so as to become better acquainted with the political/social situation of his era as well as to trace back to the origin and the unfolding of his thought and political activism. In the second part emphasis will be laid on an interpretation of various paragraphs of his Catechism with the goal of sketching a "philosophical profile" of his thought and ideology, characterized by a deep and sincere disdain of the society, its tradition and all the rules/customs that make it function. We will also see how Nechaev- due to this almost obsessive references to destruction- is paving the way for a "transcendent" possession of the revolutionary by the higher idea of destruction, with all the ontic and ontological consequences this entails for the human being when willingly submitted to this transcendence.

Finally, in the last part, we will endeavour to bring forth, through a text of Fyodor Dostoevsky, a more personal account of who Nechaev, and each Nechaev is; what makes the emergence of his thought possible and how this thought may provoke the emergence of different Nechaevs and Nechaevists, with all eventual consequences implied in our social, political and ideological sphere(s).

\section{AS A WOLF AMONG THE SHEEP: THE LIFE AND DEATH OF SERGEI NECHAEV}

When thinking about nihilism- specifically its possible materialization in the political/ social sphere- many of us would probably turn our thought towards the era of 
Russian nihilism, when the politically expressed nihilism reached its apogee with the assassination of Tsar Alexander $2^{\text {nd }}$ on the $13^{\text {th }}$ of March 1881 by Ignacy Hryniewiecki, a young member of the radical anarchist group "Narodnaya Volya (People's Will)". This long-sought assassination, if we take into account the amount of assassination attempts against the Tsar (April 1886 by Dmitry Vladimirovich Karakozov, April 1867 by Antoni Berezowski and the bloody attempt under the dining room of Tsar's Winter Palace, in February 1880, during which dozens of people got killed and many more injured by Stephan Khalthurin, also member of "People's Will"). This bloody and turbulent political situation had already found its prophet in the person of Sergei Nechaev, a Russian anarchist whose work Catechism of a Revolutionary has shaped the way that nihilism was to be understood. From that moment on, the book was converted into a dark legacy whose content is being brought back to our mind, each time we notice slaughtering perpetrated in the name of a political idea or value by radical groups inspiring to demolish the status quo of the society via the use of violent ways. Sergei Nechaev, born in Ivanovo, Russia, in 1847, was raised by parents of lower economy class. He went to Moscow at the age of 18 to work for the historian Mikhail Pogodin and a year later came to St. Petersburg to attend lectures at the St. Petersburg University. During 1868-69 he participated in student revolutionary movement(s) in the university and, finally, in March 1869, he moved to Geneva, having first spread false rumours of his arrest in St. Petersburg, with a view to making up his own myth of a revolutionary figure. In Geneva he met with the undoubted banner of the anarchist movement, Mikhail Bakunin, who seems to have got very fond of him ${ }^{1}$ and used to call him "Boy". Bakunin was full of enthusiasm about the ideologically ardent Sergei and he helped him out with everything that the latter would need in order to enable him to propagate his ideas and materialize his vision. It was during the spring of this same year that Nechaev wrote his Catechism for a Revolutionary carving, thus, his name on the stone of nihilism's history and political existence.

Having met and befriended Bakunin, Nechaev went back to Moscow. He founded a small radical revolutionary group called "Narodnaya Rasprava (People's Reprisal)" while trying to organize the society for the so called "Revolution" of his Catechism. To that effect he recruited some young students, mostly from the faculty of agriculture of the university of St. Petersburg and set in motion his plan of creating cellular radical, revolutionary groups, unknown one to another so as to avoid being detected or betrayed by other members. One of the characteristics of Nechaev's group was the required blind obedience to the leader, namely, to him. An element that led to the assassination of Ivan Ivanovich Ivanov, a member of "People's Reprisal" who, at the cost of his own life, questioned the strategy and the tactics of Nechaef. Sergei, with other members of the group, on 21 November 1869, suspecting Ivanov of giving information to the police, shot him through the head and threw his corpse to a lake. The body, though, was soon found by the police and Nechaev, in order to avoid raising more suspicions and getting arrested, opted for his going back to Switzerland.

He found there his comrade Bakunin, living then in Locarno. Bakunin put confidence in the latter's account of the events; namely that he had not killed Ivanov and that the Tsar was hunting him down for political reasons. Ready to assist his comrade in this difficult situation, Bakunin made a public defence of Nechaev in a pamphlet he published under the title "The Bears of Berne and the Bear of Petersburg"" trying to explain the inhuman fate that Nechaev would face in the hands of the Tsarist police in case he was finally arrested. However, Nechaev, firm in his callous stance of not having feelings and sentiments but simply goals, not only did he manage to economically exploit Bakunin leaving him in a very 
hard economic situation, but, also, stole some letters of Bakunin's correspondence which would compromise him in the eyes of the authorities. The total breach in their relationship, though, came when the Russian journalist, revolutionary and member of the General Council of the First International, German Lopatin, went to Switzerland and made known that the reason of Nechaev's being there was that he had actually killed Ivanov and that the proof of it were the scars on the finger of Nechaev, caused by his victim's vain to defend himself. ${ }^{3}$

Nechaev, left with no other allies, apart from his personal convictions and goals, travelled for a while to Paris and Zurich where was arrested, on 14 August 1872, and sent to Russia being accused of having killed Ivanov. In Russia he was found guilty and sentenced to 20 years "katorga"-hard labour- in a high-security cell of Peter-Paul Fortress. The cells, however, of that unbreachable fortress did not manage to bend Nechaev's "nihilistic crusade". He succeeded in taking his guards by his side and they also started calling him "eagle". ${ }^{4}$ As further proof of his charismatic ability to convince and inspire, even his enemies, Nechaev contrived to "recruit" in his bloody quest 69 guards and almost attained to set in March a jail break. ${ }^{5}$ According to the historian Paul Avrich he convinced his guards to read the journal of the illegal "People's Will" organization. ${ }^{6} \mathrm{He}$ was able to be in communication with them, and with their central committee, through correspondence; he was similarly informed of the assassination plan of Tsar Alexander $2^{\text {nd }}$, a plan which, as we have already seen, was successfully executed in March 1882. Finally, Nechaev died of scurvy in his cell at the end of 1882, at the age of 35 having left the legacy not only of his deeds, but, mainly, of his work Catechism of a Revolutionary; a work which has borne importantly upon inspiring ${ }^{7}$ nihilist/terrorist groups such as "The People's Will", German terrorists in the epoch of divided Germany and many different individuals with prominent position- among them, Eldridge Cleaver, the member of the "Black Panthers".

Nechaev's explosive personality has captured the interest of many different thinkers since then, and even the attention of Fyodor Dostoevsky who in his novel Demons worked out the fictional character Pyotr Stepanovich Verkhovensky of Nechaev. Dostoevsky, though, made a very insightful interpretation of Nechaev's idiomorphic figure, and, probably, of every Nechaev in the world, in his writing "One of Today's Falsehoods"- as we will see in the last part of our paper. Nechaev's reputation is still strong nowadays, the famous political theorist and historian Roger Griffin claiming that the extreme right parties' violent terrorist acting during the Years of Lead in Italy did occur in the "tradition of Nechaev". ${ }^{8}$ The Red Brigades and the Black Panthers, as noted before, seem to have been influenced by Nechaev's Catechism, his ideas and his passion for nihilism, proving, thus, to be indeed no less strong than his deeds and his political activism. For this reason, the next part of our work will be dedicated to a presentation of the core ideas of his Catechism accompanied by a philosophical reflection on their potentiality for nihilistic thinking and acting.

\section{NECHAEV'S CATECHISM: THE LEGACY OF NIHILISM}

In his Catechism of a Revolutionary, in the first part concerning the "Duties of the Revolutionist to himself', Nechaev argues:

1. The revolutionist is a person doomed [obrechennyi, in older usage signifying also "consecrated"]. He has no personal interests, no business affairs, no emotions, no attachments, no property, and no name. Everything in him is wholly absorbed in the single thought and the single passion for revolution.

2. The revolutionist knows that in the very depths of his being, not only in words but also in deeds, he has broken all the bonds which tie him to the civil order [grazhdanskim poriadkom] 
and the civilized world with all its laws, moralities, and customs, and with all its generally accepted conventions. He is their implacable enemy, and if he continues to live with them it is only in order to destroy them more speedily.

3. The revolutionist despises all doctrines and refuses to accept the mundane sciences, leaving them for future generations. He knows only one science: the science of destruction. For this reason, but only for this reason, he will study mechanics, physics, chemistry, and perhaps medicine. But all day and all night he studies the vital science of human beings, their characteristics and circumstances, at every possible level of social existence. The object is perpetually the same: the surest and quickest way of destroying the whole filthy order.

4. The revolutionist despises public opinion. He despises and hates the existing social morality in all its manifestations. For him, morality is everything which contributes to the triumph of the revolution. Anything that stands in its way is immoral and criminal.

What we can see in the first four passages is the creation of a new kind of human being, a "revolutionary" human(?) being whose goal is the revolution and his tool the destruction. This new kind of being is a kind of a "lone wolf", separated from the world, with no personal interests, no emotions, and no name, whose only reason for living is the passion for the revolution. Of course, having no feelings, but feeling passionate about the revolution could seem a bit contradictory. Nonetheless, everything, if we are to make sense of this pamphlet, has to be seen in the perspective of a new being which does not even want to have a name; a being which has been totally absorbed by his idea of the revolution, and, most importantly, by his lust for destruction. Having no name and desiring no name is the absolute surrender of a personality to a cause. The cause has become the person and this taking over has been welcomed by the person surrendering his own personal being to something that is supposed to be more than him and even desiring becoming the person's only passion, goal and purpose. This is why the word doomed appears in the dark horizon of Nechaev. The revolutionary is doomed, meaning that his will has become the will of the dark idea that has sentenced him into this struggle. The idea is in full possession of the man. The doom of the person is the broad horizon of the idea springing forth from his own giving up his personality. What blossoms is not a free choice but a decision which ties the person and his future to something that once decided will define his life from that moment on. The doom of the person is the being brought forth of the destruction of the world. The expression of the absolute uncanniness in a world where the only possible abode is the destruction of everything that the rest could characterize as abode and homely. Life becomes a strict duty where the only possible way towards the ontic realization of the idea, is the revolution through the destruction; a new society through the burning down of everything that constitutes a society as we know it, namely the laws, our morality and moral values, our customs and our relationship with the rest of the people. All those elements, however, are the core of what makes our society a society and their destruction in the name of revolution would require a society born out of scratch; taken out of the traditions that formed the older society, more generally, isolated from every possible interaction with all those elements that could actually make of a society a matrix of actions, interactions and social/political syntheses. Burning everything to ground so as to build something new would make sense if there was still some ground to build upon. Nechaev's approach seems to be getting lost(?) in the vortex of destruction; a destruction which denying the glorification of its own name takes occasionally the name of revolution.

Thus, the ideas of morality and values are not becoming subjective, but, on the contrary, they reach the point of becoming pure objects and tools whose only utility lies in their use for the accomplishment of the destruction and the revolution. Morality, thus, is what helps the revolution and the destruction of the "filthy order", at least from Nechaev's 
point of view. There is indeed a cruel sincerity in the thought of the Russian nihilist who does not try to hide his true intention behind ideas and values which would later be used in such a way as to justify the means. On the extreme opposite, it seems that the only idea materialized in the work of Nechaev is the destruction as a goal in itself; a concept which seems to be dominating his Catechism and his worldview in general. Anything standing against the revolutionary is criminal and immoral. Who defines, though, what a crime is if the laws and justice as well are despised and emptied of their moral content? Why does Nechaev even use the word immoral and moral if it is devoid of content? It seems that Nechaev, in his effort to ruin every possible idea of transcendence or even of the impact and influence of tradition, is just getting entangled in a much more dangerous one; a transcendence which takes the form of pure destruction disguised in different clothes according to the occasion. There is no need for morality because the world of Nechaev is quite simple and realistic. On the one side Nechaev and his society (even though poor Ivanov would have much to object to) and on the other all that oppose him. This schema gets much clearer in the fifth paragraph of the first part of the Catechism with Nechaev writing:

5. The revolutionist is a person doomed ${ }^{l 0}$ obrechennyi [see first line]. He is merciless toward the state and toward the whole formal social structure of educated society [soslovno-obrazovannogo obshchestva]; and he can expect no mercy from them. Between him and them there exists, declared or concealed, a relentless and irreconcilable war to the death. He must accustom himself to torture.

The whole social structure with its institutions and people is bound to be destroyed. No mercy will be shown to the revolutionaries and no mercy will the revolutionaries show. Not only destruction but the torture as well is something that the revolutionary has to be accustomed to. The society, as seen through the eyes of Nechaev, is the pure incarnation of the absolute enemy; an enemy deprived of his own human essence- a deprivation that the revolutionary is willingly engaged into-. Since the revolutionary decided to sacrifice his own personality and name for the sake of the destruction he can only assume that the consequence of this sacrifice is not going to be purely personal, but, on the contrary, the whole society will pay the consequences of it due to the fact that the revolutionary's feeling uncanny in the society led him to the rejection of his own personality and letting be "possessed" by the idea of destruction and of its official cloak, the revolution. Seen in another way, the nihilist revolutionary is directing his rage against the ground from which the society blossomed, forgetting that what he is and what he has become is a fruit of the same ground that gave rise to the so much despised society. Nechaev, through his idea of absolute isolation, seems willing to deny the fact that he is also the product of relationship and interaction in the society. No matter how much he despises and hates the society he does not want to accept that what he became was greatly due to a society that opened the ground for his nihilist coming forth- with the bright exception of the robber bands he considers, as we will later see, the only genuine revolutionists in Russia. Burning down the ground that gave rise to the society will not also burn his having come forth from the same ground. This is probably the reason why Nechaev avoids transforming the conflict and destruction of the society into a personal matter; an endless passionate quest against a society that has betrayed him. His having become doomed by the idea of destruction helps him distantiate himself from his society and from his own beliefs and ideas concerning the society. No sentiments could eventuate inside the revolutionary because that would put obstacles in the actualization of the destruction in the world. The destruction of the society cannot be Nechaev's destruction because that would not make it a cause and an idea but a personal vendetta; the destruction has to be impersonal, cruel and without sentiments. 
6. Tyrannical toward himself, he must be tyrannical toward others. All the gentle and enervating sentiments of kinship, love, friendship, gratitude, and even honor, must be suppressed in him and give place to the cold and single-minded passion for revolution. For him, there exists only one pleasure, one consolation, one reward, one satisfaction -- the success of the revolution. Night and day he must have but one thought, one aim -- merciless destruction. Striving cold-bloodedly and indefatigably toward this end, he must be prepared to destroy himself and to destroy with his own hands everything that stands in the path of the revolution.

7. The nature of the true revolutionist excludes all sentimentality, romanticism, infatuation, and exaltation. All private hatred and revenge must also be excluded. Revolutionary passion, practiced at every moment of the day until it becomes a habit, is to be employed with cold calculation. At all times, and in all places, the revolutionist must obey not his personal impulses, but only those which serve the cause of the revolution.

The ardent desire for destruction, as we see, has to be accompanied by a cold calculation since what matters most is the destruction of the society, the destruction of every obstacle that stands in the way of the revolutionary. It is noteworthy to point out that in Catechism the sentiments are considered distractions for the revolutionary since all that matters is the quick destruction of everything that stands in his way. We could assume that this also came from the personal experience of Nechaev who put his "friend" Bakunin, much more than once, in a perilous situation. This also goes against the modern conception of solidarity in the anarchist movements where the support of the members plays a crucial role. Nonetheless, for Nechaev everything that is not significant for the revolution loses its value. It is a bit frightening, though, to imagine a society which has blossomed through a valueless and devoid of any sentiment revolution; a "cold-blooded" revolution done through a "cold passion" and organized via a "cold calculation". Nechaev in his effort to avoid making his revolution personal he totally surrendered himself to the idea of destruction, surrendering, though, at the same time, all that would make the revolution humane. The sentiments, the joy, the pleasure and the warmth of love and companionship have all become the oil for the endless slaughtering machine of destruction. All the sacrifices made seem to have had success taking into account that Nechaev managed to inspire a much more effective than him terrorist organization ("People's Will") and if we consider that we are still speaking about him regardless of his not so successful political and social activism. The hatred, the destruction and the fury that the Catechism unleashed managed to bring nihilism seriously into the political sphere enabling the fury of destruction to dress itself with the costume of the revolutionary answer. Many terrorists have effectively used destruction in order to promote their plans, very few, though, apart from Nechaev, succeeded in making of destruction a value in itself; an idea worth killing and dying for no matter the consequences and the obstacles. Nechaev, thus, is not to be limited to an example of what happens when a human being goes astray; on the contrary, he is the best example of what happens when the human being seriously considers himself as limitless and boundless pure potentiality, even if this potentiality actualizes itself in sheer and pure destruction.

Having seen the core element of destruction in the Catechism and the possession of the person by it through the latter's surrendering his own personality and name, we could now try to understand which the goal of the revolution is and which its outcome in the society will be, especially if we recall the pure hatred expressed by Nechaev against every moral value, institution and the society as a whole. In the last part of his Catechism Nechaev titled "The Attitude of the Society ${ }^{11}$ towards the People" we read that:

22. The Society has no aim other than the complete liberation and happiness of the narod -- i.e., of the people who live by manual labor. Convinced that their emancipation and the achievement of this happiness can only come about as a result of an all-destroying popular revolt, the Society 
will use all its resources and energy toward increasing and intensifying the evils and miseries of the people until at last their patience is exhausted and they are driven to a general uprising.

The first thing that strikes us in this passage is that the only aim of the Society is the liberation and the happiness of the people. So far society has been despised, attacked and worthy of destruction; the people, however, must be happy and totally free. Their freedom and happiness, though, will be the result of the intensification and the increase of their evils, miseries and sufferings till they finally decide to rebel and merge into an uprising against the source of their sufferings which is the dominant political and economic status quo which gives the revolutionary Society no other choice than to torture and increase the misery of the people so that the latter could blame the State for their misfortune. This strategy, nonetheless, makes quite blurry the difference between the suffering caused by the State and the revolutionary Society since the latter works as an accelerator of the oppression of the former in order to bring the people to their knees. Under the aim of the happiness of the people we see a not so subtle bridge of despair and suffering which is not freely decided by the people. The Society, having decided that the people must be free and happy, uses them as its experiments to test and break their limits so as to turn them against the State. Death, despair and manipulation are required for this so-called happiness of the people helping us understand that destruction takes its toll on the well-being and the patience of the people. In addition, proclaiming that a secret Society which has banned every feeling and sentiment from its ranks will manage to create happiness in a society struck by anger, despair and suffering, also causes some really important ontological issues concerning happiness; the latter is limited to a different degree of suffering and despair and, probably a more serious methodological one, namely that the revolution as we will now see again, requires a destruction of the tradition, values, institutions and classes of the society, letting, thus, the people in a groundless situation where the only example of happiness will be presented by a group that has banned happiness from its ranks with the aim of destroying everything so that the people can be happy. Hence, in paragraph 23, we read:

23. By a revolution, the society [tovarishchestvo] does not mean an orderly revolt according to the classic western model -- a revolt which always stops short of attacking the rights of property and the traditional social systems of so-called civilization and morality. Until now, such a revolution has always limited itself to the overthrow of one political form in order to replace it by another, thereby attempting to bring about a so-called revolutionary state. The only form of revolution beneficial to the people is one which destroys the entire State to the roots and exterminates all the state traditions, institutions, and classes [klassy] in Russia.

As we can understand, the revolution of Nechaev is pure havoc. The civilization, morality, tradition and the whole State have to be eradicated so that the people may benefit from this downfall. The question, however, remains who the founder of this new society will be. This is a question of limited significance for Nechaev, since his role, and his organization's role, is a different one:

24. With this end in view, the Society therefore refuses to impose any new organization from above. Any future organization will doubtless work its way through the movement and life of the people; but this is a matter for future generations to decide. Our task is terrible, total, universal, and merciless destruction.

According to Nechaev there is no doubt that an organization in the future will find its way to create another kind of society in the times to come. This is not a concern for him since his task is a different one: total, universal and merciless destruction. There is no emphasizing on the hope of better future, of a better society or of a solidary society in the model proposed by Prince Kropotkin in his Mutual Aid. The lack of any further reference to the new society is closely tied to the fact that Nechaev is a prophet of destruction, not of 
peace and founding. Merciless destruction and eradication of all the institutions and traditions characterize his thought, not the well-being of a future society. His thought is endlessly driven by the vortex of destruction and mayhem; a vortex, though, that has managed to keep his thought alive and effective even centuries after his death. Peace and cohesion belong to the future; the present is destruction and endless hunting down of the enemy. The enemy, however, has become an abstract entity since there is no place where he cannot be found: he is in the tradition, in the institutions, in the State, in the laws and in the moral behaviour. How can you ever stop a war when the war is raged against everything surrounding us?

25. Therefore, in drawing closer to the people, we must above all make common cause with those elements of the masses which, since the foundation of the state of Muscovy, have never ceased to protest, not only in words but in deeds, against everything directly or indirectly connected with the state: against nobility, against bureaucracy [chinovnichestva], against priests, against the merchant gild, and against the parasitic kulak [rich peasant]. We must unite with the world of adventurous robber bands, the only genuine revolutionists in Russia.

In this passage we see that the relation with the people has to be one of getting closer, so as to achieve the goal of the destruction of all. No empathy is expressed for their suffering-how could it be if Nechaev's goal was to multiplicate their suffering- only the will to stand close to those who have always protested and attacked the State and everything connected with the latter: the nobility, the bureaucracy, the priests and the rich people. Solidarity is understood in terms of the maximisation of the utility. This lack of sympathy is explicitly expressed in the paragraph 13 of the Catechism, ("The Relations of the Revolutionist within [his revolutionary] Society"), when Nechaev says:

13. The revolutionist enters the world of the state, of the privileged classes [soslovnyi...mir], of the so-called civilization, and he lives in this world only for the purpose of bringing about its speedy and total destruction. He is not a revolutionist if he has any sympathy for this world. He should not hesitate to destroy any position, any place, or any man in this world. He must hate everyone and everything in it with an equal hatred. All the worse for him if he has any relations with parents, friends, or lovers; he is no longer a revolutionist if he is swayed by these relationships.

Rarely have we seen such a direct attack against the idea of the world and everything that it represents. No sympathy, no feelings just the will of nothingness and an endless lust for nihilism. The possession of Nechaev by the idea of destruction is so clear and explicit that there can be no question why his ideas have still survived and are still inspiring radicals. The pamphlet Catechism is a compass for the obscure transcendental possession by the idea of destruction. A constant burning into ashes of the whole society for the sake of destruction, since the future generations will have to think of the way to found a new society. The human being of Nechaev has its reason of being in the not-being of everything that is supposedly enchaining him, even if this is the whole world. Nechaev's human being has only one purpose, one value and one task,

26. To weld this world into one single unconquerable and all-destructive force -- this is our organization [organizatsiia], our conspiracy, our task.

\section{INSIDE THE SOUL OF A "DEMON": DOSTOEVSKY AND THE SPIRIT OF NECHAEVISM}

Having seen some core elements of Nechaev's philosophy and its sincere and profound relationship with the idea of destruction, a question that could easily arise is the following one: what makes someone become a hardcore and absolute nihilist such as Nechaev? One of the possible answers was given in the following comment published in the journal Russian World ${ }^{12}$ after the publishing of Dostoevsky's book Demons: 
. . we think that the Nechaev case ought to convince us that students in Russia do not get mixed up in such lunacy. An idiotic fanatic such as Nechaev could find proselytes only among the idle and underdeveloped and not among young people involved in studies.

From the above extract we can deduce that Nechaev was a lunatic, idiotic fanatic who could find supporters only among the "idle and underdeveloped", and not among people with studies. That was the main idea of the presented text; an idea/defence of people, who unlike Dostoevsky, tried to analyse everything from a superficial point of view so as to avoid cutting deep into the dark potentiality of each human being. History, though, decades later, would prove to them that excellent studies and delicate taste in classical music is not incompatible with slaughter and fanaticism, not even with concentration camps. Choosing the easy way to interpret and understand what Nechaev is, creating an image of a perverse and distorted version of our Not-I, was not, however, the proper way to analyse Nechaev, as the survival and the influence of his ideas in later generations has already proven. There was something more than idiocy and fanaticism in that young man who managed to recruit 69 guards while imprisoned. Dostoevsky's approach was much more profound since he saw something more in Nechaev as this comes out from the following extensive passage written as an answer ${ }^{13}$ to the Russian World's publication:

Please, gentlemen (I am speaking in general and not only to the writer from The Russian World), on the basis of your "denial of the fact" you assert that the Nechaevs absolutely must be idiots, "idiotic fanatics." Is that really so? Is that just? In the present instance I set Nechaev aside and say " Nechaevs," in the plural. Yes, among the Nechaevs there can be creatures who are very shadowy, very dismal and misshapen, with a thirst for intrigue and power of most complex origins, with a passionate and pathologically premature urge to express their personalities, but why must they be "idiots?" On the contrary, even the genuine monsters among them may be very well developed, extremely clever, and even educated people. Or do you think that knowledge, a course of training, a few facts picked up in school (or even in university) form the soul of a youth so thoroughly that with the receipt of his diploma he at once acquires an unfailing talisman that once and for all enables him to recognize the truth and avoid temptations, passions, and vices? And so, by your way of thinking, all these youths who complete their studies at once become something like a multitude of little popes with the power of infallibility. And why do you suppose that the Nechaevs must absolutely be fanatics? Very often they are simply scoundrels. "I am a scoundrel, not a socialist," says one Nechaev. True, he says that in my novel The Devils, but I assure you that he could have said it in real life. These scoundrels are very crafty and have thoroughly studied the magnanimous aspect of the human soul-and most often the soul of youthso as to be able to play on it as on a musical instrument.

Dostoevsky in this diachronic critique against the bureaucratic and calculative spirit of his, and ours as well, era brings down one by one the over simplistic characterizations set against Nechaev. Idiocy and fanaticism are not sine qua non conditions for our understanding of Nechaev and each Nechaev. What grasps our attention, among other things, is the interpretation of $\operatorname{Nechaev(s)}$ as a human being "with a passionate and pathologically premature urge to express their personalities". In one sentence Dostoevsky brings to a collapse the whole effort of Nechaev to be seen as an impersonal actor of destruction and a bloody seeker of revolution; an actor who has willingly sacrificed his name, his feelings and his sympathy for the world on the altar of destruction and of a bloody cleansing. Right behind this idea of a destruction we discern a person who has dedicated his all being into depersonalizing himself for the sake of something greater than him, not realizing, though, that what he managed to bring forth was not a transcendental value of the destruction or/and revolution, but his own personal actualizing of his potentiality as the most destructive and bloodthirsty version of himself. The itinerary of the idea was not upside down, as a preparation for the possession of a higher idea, but rather downside up; a bloody ascension of a person who wanted to become something more than himself, the incarnation of 
destruction, even if that meant the violent ripping apart of everything that made him human and a person.

Summarizing the above said, the Russian thinker, as we see in the above passage, sets upon the dismantling of both characterizations of idiocy and fanaticism. Nechaev, far from being an idiot is someone who could easily be extremely clever, given that intelligence is not only to be proved by the diploma and the official-bureaucratic-recognition of it; a diploma which once acquired separates the "few" from the uneducated masses which would later become the new Nechaevs. Nor is Nechaev, and every Nechaev, necessarily a fanatic or a lunatic absorbed by his ideas and incapable of seeing anything outside his ideological and philosophical vision. As Dostoevsky says, Nechaev could be just a "scoundrel" with the ability, though, of manipulating young people's souls finding each moment the correct radical and violent tune. Simpler said, Nechaev did not have to be a living prophet in order to be recognized as such afterwards. It would not be an exaggeration if to say that Nechaev's deeds fall short compared to the nihilist dimension his thought had opened for future generations. What Nechaev had truly in his mind we will never know-even though we can be quite certain that till the last moment he was quite committed to his worldview, considering what he managed to do at jail and if we give validity to the rumours that he denied the help of "People's Will" to organize his escape because he did not want to distract them from their main goal of killing the Tsar - but what we can definitely see is that he did exercise his influence on both his contemporary ("People's Will") and future generations of radical terrorists and nihilists. Knowing whether he truly was a fanatic or not, of course it is important for a philosopher or probably a psychologist, but it is not the only premise that conditions the thinking and actions that took place paying honour to his thought. Dostoevsky was able to see that the "domino of ideas" is a strange game where each part can be brought down for different reasons, keeping up, nonetheless, with the flowing of the thought of Nechaev and little does it matter how each one interpreted it. Once the seed of the idea of nihilism has been planted, then, different ideas may start flourishing, all different aspects of the same nihilistic seed.

The fact that the followers of Nechaev, as well, should not be simplistically characterized as idiotic fanatics or just "loafers" and marginalized people is highlighted by Dostoevsky's giving an account of a very personal experience ${ }^{14}$ that had brought him close to death:

And do you really think that the proselytes whom some such Nechaev could gather in Russia must absolutely consist only of loafers? I don't believe that; not all of them would be. I myself am an old "Nechaevist"; I also stood on the scaffold condemned to death, and I assure you that I stood in the company of educated people. Almost that whole company had graduated from the highest institutions of learning. Some of them, later on, when everything had passed, distinguished themselves by making remarkable contributions to specialized fields. No, gentlemen, the Nechaevists do not always come only from idlers who have never studied anything.....

Finally, one interesting issue that arises here is the difference between being a Nechaev and being a Nechaevist; namely, between being the one who sets the bloody example and the one who follows it having idolized the martyr/prophet who dedicated his life to the cause, the latter becoming, very often, much bloodier and fiercer than the former in his struggle to live up to the glorified ideological heritage he has become part of. Following Nechaev makes someone not another Nechaev but a disciple of him; someone who could adapt what Nechaev thought to the context in which he lives in so as to maximize the utility of the means needed for the destruction of the "filthy order". Nechaev's Catechism is written in such a way that avoids its being limited to specific social/political context. It has 
the apocalyptic tone of a constant call to arms for the forging of a better society; a society, nonetheless, whose foundation lies on a future generation which will "doubtlessly" find the way to make everyone happy. What makes this approach dangerous, though, is that the revolutionary takes the shape of a martyr doomed to find and destroy so that the next generation may be freed of all those factors which have to be destroyed. Destruction is sanctified in the fire of the "revolution"; a revolution that serves in an excellent way the thirst of destruction since the latter is not seen as a senseless nihilating ouroboros activity, but it postulates a brighter future which can only be achieved through the absolute darkness of political nihilism. These elements of martyrdom and "self-sacrifice", the image of a revolutionary getting his hands dirty for a future "better good" should be seriously considered when dealing with radical groups; a piece of advice that Dostoevsky gave us in the clearest way; ${ }^{15}$

But let that be; I was a member of the Petrashevsky Circle, then. How do you know that the members of that circle could not have become Nechaevists, i.e ., set off on Nechaev's path, in the event that things had taken such a tum? Of course, one couldn't even have imagined that at the time: how could things have ever taken such a tum? Times then were completely different. But let me say one thing about myself alone: a Nechaev I probably could never have become, but a Nechaevist-well, of that I can't be sure; perhaps I could have become one . . . in the days of my youth.

\section{CONCLUSIONS}

Having reached the conclusion of this paper, we would like to stress one point concerning how Nechaev could be interpreted and which his significance is for our understanding the human being in general. Schelling in his brilliant and deep-reaching Freedom Essay explains the struggle taking place inside the human being between the "Ground" and the "Existence", the urging and the understanding. We are caught between our desire to become one with the universal order, with the revelation of Logos in our lives, while, at the same moment, we do not want to surrender our personality, our self and our will to something which is not a pure I. When acting evil, hence, we act in such a way as to make the universal submit to our own will, to our own way of understanding and acting in the world. The "pathological urge to express the personality", as Dostoevsky very accurately commented, is our will to be the centre of the universe, even if that means the burning down of all that is not considered ours. Nechaev is nothing more than this extreme potentiality of the human being getting actualized. His ardent hatred for the society and its rules, his obsession with the destruction and with the necessity of creating a new being which little has to do with the human as being we know it, are all different violent and radical expressions of the same core; namely, our belief that we can and should be the centre of the universe. Nechaev is the case of an I which has willingly surrendered itself to the idea of destruction so as to hide from the others- and even from himself- that the whole process of being possessed by destruction is not a sacrifice of the I, but, on the contrary, its fullest glorification expressed in the (f)act of the absolute refusal of a world that the supposedly sacrificed I did not tolerate not to have it as its own. It seems that even in the act of the dehumanization of the self by the idea of destruction- so that a new being may finally emerge- the impersonal revolutionary, the power that still holds control of the whole dehumanizing process is the humane desperate search of a human who seeks to find an abode in the world, even if this abode is scorched earth and misanthropy. 


\section{FOOTNOTES}

\footnotetext{
${ }^{1}$ For more information about the life of Nechaev and his relation with Bakunin, see: Paul Avrich. Bakunin and Nechaev. London: Freedom Press. 1974 and the introduction and preliminary notes of the Spanish tradition of Nechaev's Catechism of a Revolutionary: Sergéi Nechayev. El Catecismo Revolucionario. Madrid: La Felguera. 2014

${ }^{2}$ For an English translation of the pamphlet see: Mikhail Bakunin. "The Bears of Berne and the Bear of SaintPetersburg" (Trans. by Shawn Wilbur). The Libertarian Labyrinth.31 March 2014. Retrieved from: https://www.libertarian-labyrinth.org/bakunin-library/the-bears-of-berne-and-the-bear-of-saint-petersburg$1870 /$

${ }^{3}$ Paul Avrich. Anarchist portraits. Princeton: Princeton University Press. 1990. p.44

${ }^{4}$ Ibid. p.49

${ }^{5}$ Anatol Rapoport. The Origins of Violence: Approaches to the Study of Conflict. New Jersey: Transaction Publishers. 1995. p. 186

${ }^{6}$ Paul Avrich. Anarchist portraits. p.49

${ }^{7}$ For more information concerning the possible influence of Nechaev on various international terrorist groups see the first chapter "Organizing Revolution: The Russian Terrorists" in Steven Marks. How Russia Shaped the Modern World: From Art to Anti-Semitism, Ballet to Bolshevism. Princeton: Princeton University Press. 2004

${ }^{8}$ Roger Griffin. Terrorist's Creed. Basingstoke: United Kingdom.2012. p.49

${ }^{9}$ The translation that we will be using, with slight alterations, is the one provided online by the University of Oregon (the translation can be found here: http://pages.uoregon.edu/kimball/Nqv.catechism.thm.htm) and it has been verified by comparison with the Spanish translation of the work: Sergéi Nechayev. El Catecismo Revolucionario. Madrid: La Felguera. 2014

${ }^{10}$ The word does not appear in the fragment. It has been put here for reasons of clarification.

${ }^{11}$ The Society in the title is to be understood as the revolutionary society formed by the revolutionary so as to achieve his goals.

${ }_{12}$ Fyodor Dostoevsky. A Writer's Diary- Volume 1. (Trans. By Kenneth Lantz). Illinois: Northwestern University Press. 1993. p. 279

${ }^{13}$ Ibid. p. 283

${ }^{14}$ Ibid. p. 284

${ }^{15}$ Ibid.
}

\section{BIBLIOGRAPHY:}

[1] Anatol Rapoport. The Origins of Violence: Approaches to the Study of Conflict. New Jersey: Transaction Publishers. 1995. p. 186

[2] Fyodor Dostoevsky. A Writer's Diary- Volume 1. (Trans. By Kenneth Lantz). Illinois: Northwestern University Press. 1993. p. 279

[3] Mikhail Bakunin. "The Bears of Berne and the Bear of Saint-Petersburg" (Trans. by Shawn Wilbur). The Libertarian Labyrinth.31 March 2014. Retrieved from: https://www.libertarianlabyrinth.org/bakunin-library/the-bears-of-berne-and-the-bear-of-saint-petersburg-1870/

[4] Paul Avrich. Bakunin and Nechaev. London: Freedom Press. 1974

[5] Paul Avrich. Anarchist portraits. Princeton: Princeton University Press. 1990. p.44

[6] Roger Griffin. Terrorist's Creed. Basingstoke: United Kingdom.2012. p.49

[7] Sergei Nechaev. Catechism of a Revolutionist. (Trans. by University of Oregon-Online Edition). University of Oregon. Retrieved from: http://pages.uoregon.edu/kimball/Nqv.catechism.thm.htm ${ }^{15}$

[8] Sergéi Nechayev. El Catecismo Revolucionario. Madrid: La Felguera. 2014

[9] Steven Marks. How Russia Shaped the Modern World: From Art to Anti-Semitism, Ballet to Bolshevism. Princeton: Princeton University Press. 2004 